\title{
Paule Petitier, 1830 ou les métamorphoses du centre (Michelet, Balzac, Hugo)
}

\section{Marco Stupazzoni}

\section{Q OpenEdition}

1 Journals

\section{Edizione digitale}

URL: http://journals.openedition.org/studifrancesi/34896

DOI: $10.4000 /$ studifrancesi.34896

ISSN: 2421-5856

\section{Editore}

Rosenberg \& Sellier

\section{Edizione cartacea}

Data di pubblicazione: 1 novembre 2005

Paginazione: 431

ISSN: 0039-2944

\section{Notizia bibliografica digitale}

Marco Stupazzoni, «Paule Petitier, 1830 ou les métamorphoses du centre (Michelet, Balzac, Hugo)», Studi Francesi [Online], 146 (XLIX | II) | 2005, online dal 30 novembre 2015, consultato il 19 avril 2021. URL: http://journals.openedition.org/studifrancesi/34896; DOI: https://doi.org/10.4000/studifrancesi. 34896

Questo documento è stato generato automaticamente il 19 avril 2021.

\section{(c)}

Studi Francesi è distribuita con Licenza Creative Commons Attribuzione - Non commerciale - Non opere derivate 4.0 Internazionale. 


\section{Paule Petitier, 1830 ou les} métamorphoses du centre (Michelet,
Balzac, Hugo)

Marco Stupazzoni

\section{NOTIZIA}

PAULE PETITIER, 1830 ou les métamorphoses du centre (Michelet, Balzac, Hugo), «Romantisme», $\mathrm{N}^{\circ} 123$, 1er trimestre 2004, pp. 7-20.

1 In questo studio, l'autore mette in luce l'importanza del concetto di centre nella produzione letteraria posteriore alla Révolution de Juillet in relazione alle modalità di rappresentazione della società e della politica. Gli eventi e i mutamenti che segnano il 1830 hanno favorito il processo di trasformazione dell'idea di centralità trascendente incarnata dal sovrano in quella di una centralità immanente profondamente legata alla realtà: se Michelet celebra, nell'Introduction à l'histoire universelle, la centralità della nazione come totalità autonoma, Balzac (La Peau de chagrin, Le Médecin de campagne) e Hugo (Notre-Dame de Paris) denunciano al contrario le insufficienze di questa concezione socio-politica opponendo ad essa un progetto intellettuale ed estetico intimamente legato al ruolo e alla missione dell'artista. 